\title{
Rehabilitation Of Multiple Difficult Circumstance Children Through Psycho-Social Care Mediums
}

\author{
${ }^{1}$ G.Sam Sangeeth, ${ }^{2}$ Mr.Karappaswamy \\ ICSSR Doctoral Fellow in Social Work, Bishop Heber College,researchhand4u@gmail.com. \\ Director, READ, Sathiyamagalam.
}

\begin{abstract}
The aim of the case study is to demonstrate case formulation procedure by the researcher and to teach as a recording model in capacity building programme. It enhances case study formulation skillsfor motivators/community level workers in activity centers for promoting the marginalised community childrens holistic development. The need is to promote multiple difficult circumstance children attain holistic development in the individual, family and community levels. On the basis ofthe projective techniquepsychosocial care mediums are administered. The case study was conducted with a purpose that the child who had entangled with multiple difficult circumstances must be liberated using PSC mediums.The case study is followed by intervention ment exclusively for develoment and empowerment multiple difficult circumstance children. The PSC mediums includes Facial expressions, Thematic story cards, Family protrait, Drawing, Writting, Dolls and Clay modelling. The outcome of the case study is developed through psychosocial care mediums with the process of enriching psychosocial well-being. The wellness obtained are throughmastering emotions, improvement in communication, adoption to stress and anger management skills, understand the development and changes through peer interaction, positive behavioural change from deviant behaviour, positive attitudinal change, building their self esteem, imbibing skills for development, decision making and problem solving, improved disciplinary life amoung children.improved relationships by avioding fake friends and coordination and cooperation with the peer group are enhanced. Through constant followups, wellbeing can be aceived which has to be sustained. It can positively impact other stages of life.
\end{abstract}

Key words:Psychosocial care, support, rehabiitation, mediums, Difficult circumstances, children.

\section{INTRODUCTION}

The children in India are exposed tomultiple situation. The development of children is in our (stakeholders working for development of vulnerable children) hands. Let us not show or sow seeds of discrimination by any mean in the tender heart and minds of children. Inclusion must be our strong stand where make whole world inclusive. According to Sekar et al.,(2012).The people are marginalised by labelling them under caste, religion, economy and social status are making them vulnerable to attrocities in the society.Children falling under the catory of marginalisation are in difficult circumstances.According to Sam sangeeth et al.,(2012). identified 24 different difficult circumstances children among South India. Some of them are Children without parental care, Schedule caste \& tribe children, Single parent children, Differently abled children, Child labour, Run-away children, Children of alcoholic and substance use children etc. Psychosocial care is imperative for children experiencing vivid difficulties in their life to prevent the pathological developments that may arise and aloofs them from mainsteaming to exclusion in the society. The psychosocial care mediums works as a emancipatory function in the process of care,support, rehabilitation.

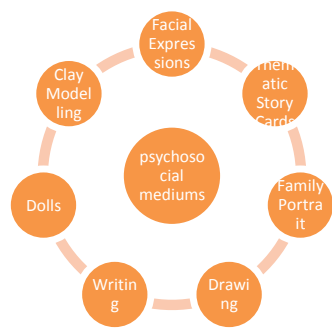

\section{PSYCHOSOCIAL MEDIUMS}

Directions for administering for administering only one stage of activity can be conducted a day, using psychosocial techniques is a must which includes creating safe, secure and conducive atmosphere for arunthathiyar children, letting the arunthathiyar children to speak [catharthis], avoiding comparison amoung arunthathiyar children, address the emotional and social needs of arunthathiyar children and record arunthathiyar children outcomes must be adhered in gendral.Projective technique methodology was used 


\section{SOCIO DEMOGRAPHIC DETAILS}

$\begin{array}{ll}\text { Name } & \text { : Master Raju [name changed] } \\ \text { Gender } & : \text { Male } \\ \text { Religion } & \text { : Hindu } \\ \text { Caste } & \text { : SC [Arunthathiyar] } \\ \text { Language spoken at home } & : \text { Telugu } \\ \text { Status of difficult circumstance } & : \text { Arunthathiyar child with inadequate parental care, } \\ \text { Orthopedically hadicapped and school } & \text { drop-out. }\end{array}$

\section{CASE VIGNETE-ONE}

Family constellation

\begin{tabular}{|l|l|l|l|l|l|l|}
\hline $\begin{array}{c}\text { Sr. } \\
\text { No. }\end{array}$ & \multicolumn{1}{|c|}{ Names } & $\begin{array}{l}\text { Relationship with } \\
\text { respondents }\end{array}$ & Age & \multicolumn{1}{|c|}{ Education } & Occupation & \multicolumn{1}{|c|}{ Income } \\
\hline 01 & Raju & Self & 15 & $\begin{array}{l}10^{\text {th }} \text { std[drop- } \\
\text { out] }\end{array}$ & $\begin{array}{l}\text { Mechanic } \\
\text { work shop }\end{array}$ & 100 rs weekly \\
\hline 02 & Maheswaran & Father & 40 & 8 std & $\begin{array}{l}\text { Taylor-own } \\
\text { shop }\end{array}$ & $\begin{array}{l}2000 \\
\text { [approximately] }\end{array}$ \\
\hline 03 & Jothimani & Mother & 30 & Illiterate & Coolie & 500 weekly \\
\hline 04 & Uma maheswari & Sister & 19 & B.com & Student & - \\
\hline
\end{tabular}

We were living as a healthy family, sudden change has taken place in our family. The change has created negative impact which is very difficult to express. We are four members in our family. As we were happy and peaceful, our unity was challenged and my father and my mother started have misunderstanding. Due to extra marital affairs of my father, he was separated from us. Now I, my mother and sister are unhappy and sad when we recollect of my father's separation. When misunderstanding has started my father's attitude started to change. He started use rude and hurting words pick unnecessary quarrels, started to beat me and my mother often for no reason, he started to hate me. Before he was very kind and he liked me very much. He understands me well about my strength and weakness. He spends much time with me, encouraging me to study and play. When I think of my troubles I feel like running away from my home. My mother knowing my state uses kind words amidst great agony which she is encountering in the way of life. She does not beat me. She likes me and spends time with me and encourages me in my life to study. I and my sister will be united always . We won't quarrel with each other.

I like my school very much. Due to difficulty in studies I used to neglect going to school. My parents were very supportive by encouraging me and taking me to school and leaving me to my teachers. Even my teachers used to be friendly and motivating me by telling me to utilize schemes which are for disabled and emphasise on employment opportunities in government exclusive for disabled in future. All these were encouraging me even worries of my life was constantly disturbing my studies amidst of my learning difficulty. In my school I used to get afraid and never ask my doubts due to my fear of my teachers even thou they encourage me. I like my school because of good drinking water, good toilet for students without disabilities, play ground, library and shady trees facilities in my school. I like my class room environment but I will be very much happy if my school is disabled friendly environment school. I find difficult to study so my teachers use to beat me and scolds me to improve but I do not want to go to school.

We are residing among arunthathiyar community in sichrasampalayam village at erode district. I love my arunthathiyar community members. We have a house construct by government built house exclusive for dalit families to live in. We have only two rooms, one we use as bed room and another we use as kitchen to cook for us. Community members used to scolds us badly and speak ill about my disability and my father's behavior but now the bad impression started to fade in our community.

\section{COMMON PROCESS FOR CONDUCTING SEVEN MEDIUMS:}

* Select a clean, calm, and peaceful place without any distraction.

* Form a group with 5-6 members.

* Building bonding with children is vital

* Inform the children that he/she is going to play a game.

* Ask for their interest and start the game.

* Inform the children not to disclose any information outside the group or critisize each other and create one ness amoung the group members.

* Give equal priority to children in the group to narrate their own life events. 
* Give adequate time to express.Donot be in hurry up wrap soon.

* No time constrains should be given to express verbally, writing or by activity.

* Donot be judgemental but allow them to express.

* Donot allow them to copy any activity in the game. Make them to sit in a spacious environment.

\section{FACIAL EXPRESSION CARDS}

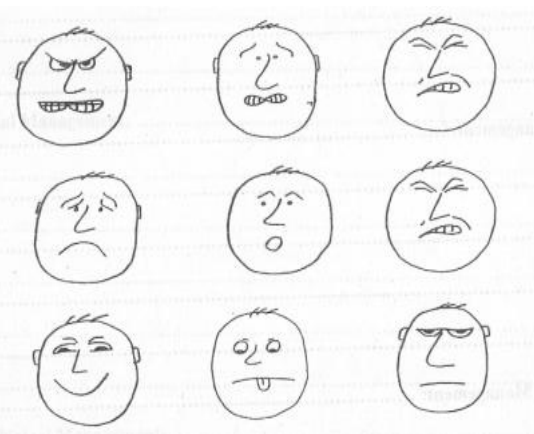

Facial expression cards are implemented with arunthathiyar children in three stages - the feeling of the arunthathiyar child on present situation, impact of difficult situation and arunthathiyar child's feelings about it and how then arunthathiyar child sees the future. Facial expression cards is one of the psychosocial care mediums that is used for the arunthathiyar children to bring out their emotions and feelings on a particular incident. The activity helps to bring out what the arunthathiyar child feels about a particular difficult situation or incident to the surface. This medium could be used as a tool for ventilation to bring out the disturbing events in an arunthathiyar child's life and the emotional feelings of the arunthathiyar child on the particular event can be identified using this medium. The activity on facial expressing is not just about unhappy events. This model could also be used to discover what makes a arunthathiyar child happy and thus guide him / her to move towards the future with optimism.

AIM: Tounderstand the arunthathiyar child's feelings about a certain difficult event, issue or individual in his/her life and to discover what kind of helps the child needs to cope with difficult situation with the help of predawn facial expressions.

\section{PROCESS:}

i. Spread the facial expression on the ground.

ii. Motivator should ask the children to pick up facial expression card according to the dominent feelings/emotions occuring across their lives.

iii. After selecting the card, the motivator should ask for reason for selecting the card and based on the reasons facilitating questions should be asked for maximum of feelings/emotions.

iv. The process of using the facial expressions has to be repeated for the stages.

\section{Stage 1- Childs feelings about oneself in present situation}

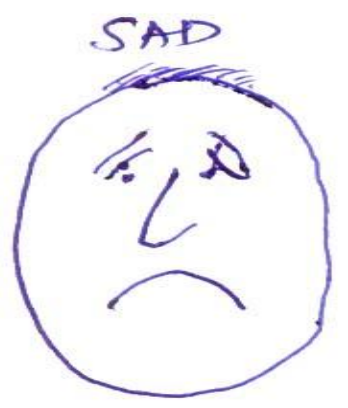

The child picked up sad facial expression card and gave reson for selecting sad expression stating that at present my mother is having more debts which she has received to built the house, to educate my sister, to keep a shop for my father. My father who had married another strange women as his wife. Initially my father was returning home occasionally, once in a week. As our debts started increasing, debtor started to come frequently and constrain my mother by abusing her verbally and another side we were facing difficulty to pay college fees for my sister. Since i going through this path my heart breaks and I used to cry in my solitary. i stopped my studies and started to go to welding workshop at sathiyamagalam.when I think of my father I get some times angry because he didn't consider that I am differently abled person and my sister who is studying. 


\section{Stage 2 - Impact of difficult situation and child's feelings about it.}

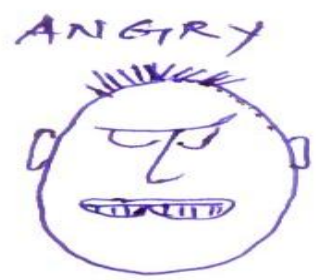

The child picked up angry facial expression card and gave reason for selecting angry expression stating thattill 2008 my family was happy. My family was a tailor and started an own tailoring shop at pulliyampatti.He used to travel daily to pulliyampatti and do his work. As he was working in that place he had illegal connections with a strange woman in that place. After he was neglecting daily return to our home and he was making visit rarely and due to which intensified quarrels started in our home.joy and peace started to decrease in our family.I and my sister were witnessing the quarrels which used to take place in our home and shed tears. My father had married a strange women. We were put up in a helpless and get afraid about behavior of our father towards us.i feel very pity for our family. Since misunderstanding arises due to illegal contact of my father, my sister enquired about it and fought with my daddy.My daddy also got angry and left the home permanently. He didn't return till now.My mother who had lost patience and gave petition in the women police wing. My father's second marriage and financial problems made me to stop me to go to schoolhapply and this incident and situation had destroyed our family which is painful and humiliating us.

\section{Stage 3 - Planning regarding future}

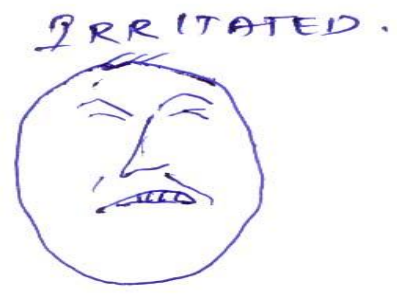

The child picked up irritated facial expression card and gave reason for selecting irritated expression stating that my future plan is to earn well and look after my sister and mother well.

THEMATIC STORY CARDS

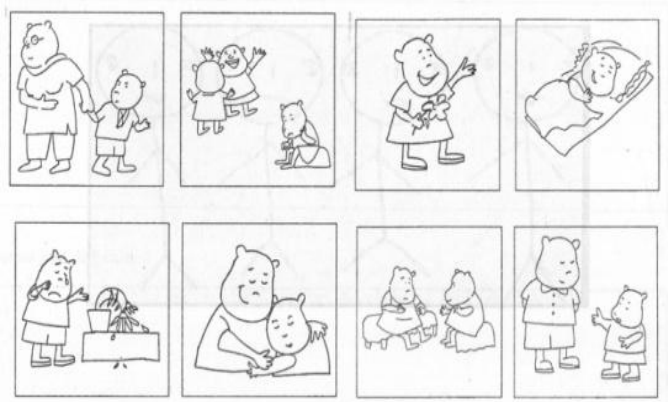

Thematic story cards are used in four stages amoung arunthathiyar children - story in my life, feelings about difficult situation, problems in life and how I see my future. Narrating life incidences and experiences with the help of thematic cards is one amoung the creative art therapies which arunthathiyar children can relate some of their life incidences to the pictures. The picture takes them back to the incidences attached to some of the black memories that young survivors of the difficult circumstance have repressed and not been able to explain or rationalize. So when the pictures are laid down in front of them, they are able to recollect the incidents and undesrtand what and why it happend to them. The encouragement from the facilitator will help them realize that the feeling of despair, anger or frustration resulting from the situation was not irrational. Arunthathiyar children during the exercise also will get to think and remember of good times and learn to approach the future with positivism. 
AIM: To make arunthathiyar children comfortable with the concept of thematic cards and help them relate it to their lives. The use of thematic story cards will help the child to ventilate their feelings and emotions related to difficult situations that they have faced or facing.

PROCESS:

i. Spread the thematic cards on a table.

ii. Form a semi-circle and ask children to round the table to select and pick up a card which is appropriatly alarming event in their lives related to thematic cards by the sight on thematic cards.

iii. Probe on reason for selecting the card.

iv. Ask them to share in the group.

\section{Stage 1 - Story in my life}

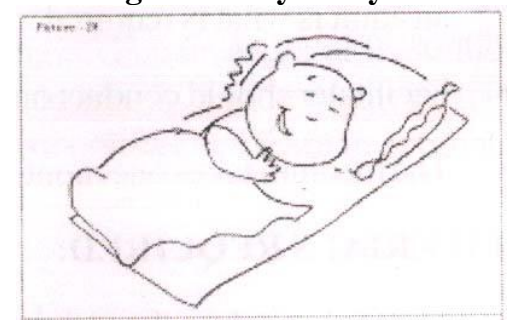

In my house my self my and my sister are living to gether. $i$ am orthopedically inadequate with locomotor impairment. It is difficult for me to walk and go to for distance. All my school class mates walk fast and $i$ will be going very slow from my village, my middle school is situated in $1 \mathrm{~km}$ distance. Daily it is difficult to go to the school and come back. I used walk alone slowly to school. I am unable to play equally with my classmates. It very sorrowfull for me when $i$ think about my difficulty in walking. I am feeling difficult to attend the school. Due to my mother's compulsion $i$ had attended till $8^{\text {th }}$ std in that school itself. In my $9^{\text {th }}$ std I joined in Thoddampalayam. Higher secontary school,during this time my father had remarried and the debt which was received to built our house was stagnated.These incidents were making me more unhappy. My father has not turned back to my home. When I am studying $10^{\text {th }}$ std my interest started to decline and 1 stoped my studies due to these disturbing factors .1 am unable to concentrate my studies and do my home assignment my teachers used to scould me because $i$ am lagging behind in my studies. Because of my inability $i$ stoped my studies. After some days my mother thought that $i$ will be spoiled by wandering meaningless in the village with fake friends. She made me to join a wedding work shop at sathyamangalam. My sister in studying B.Com in ooty. Beyond all problem my mother in very much interested in educating us.

\section{Stage 2 : My difficult circumstance in life?}

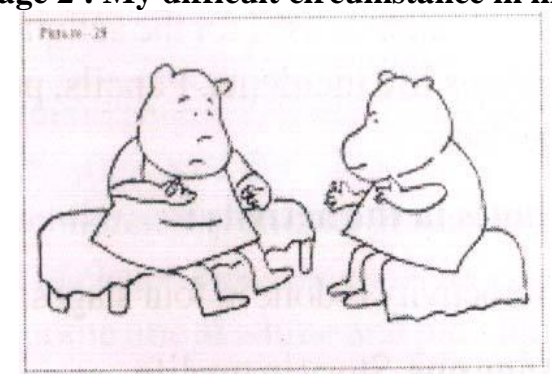

My father had second marriage and departed from us. This is the difficult circumstance in life. All the residence and our village members used to speak bad about our family and we will not come out of our home. It was very difficult to face our friends. I felt inferior.My mother used to pacify us and sent us to school. Inner feelings used to voice out with in my self that "My father has unconsciously left us and i am alone". I am unable to concentrate on my studies. My mother also doesn't have parents to ventilate her feellings. She bearing greater respansibilityof protecting family alone. We have no help to be sought. My father is the cause for disturbed life. When i feel about my situation bitterness emerges in my heart.

Stage 3 Problem in life:

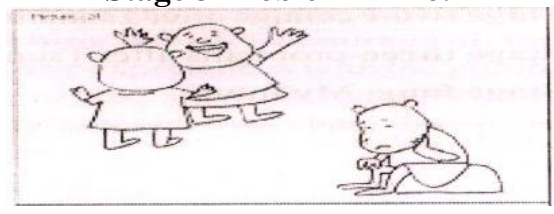


The debt received cannot be repaid. These debt are received to built the house and to make us to study.The usury daily used to come to our house and verbally abuse my mother and go. We used to get afraid thinking that when the usury will come and how we are going to manage him. Because of lack of money we were unable to pay the college fees. The construction of our house has been stagnated still. The village members of our village started to speak illabout our self. Since $i$ had intersted to go for work. The work which I $m$ doing is very hard and $i$ was unable to do it. We used to cry some times, when we think about our father's departure from us and not enqurring about us and we not knowing his where abouts.

\section{Stage 4:My future}

I have to endure all these problems and defeat it and $i$ have to protect my mother who is parenting us very well with hardships. I have to become a mechanic and earn more money and $i$ have to make my sister get married in a good place.

\section{FAMILY POTRAIT}

The family of dolls is yet another medium which is conducted in one phase, through which the arunthathiyar child narrates a story from his/her life. Two of the key reasons why arunthathiyar children find difficulty in sharing personal experience are because of their "inhibitions" and "lack of clarity in thought". In the exercise for story telling children tell their stories with the help of puppets and dolls. They could come over their inhibitions when they hear the teacher or facilitator share his/her own experiences. Through the probing of right questions an arunthathiyar child's mind could be explored and in turn the arunthathiyar child will get clarity of own thoughts and feelings. Thus the ventilation of the repressed memories through the activity of "dolls" will make the arunthathiyar child feel better.

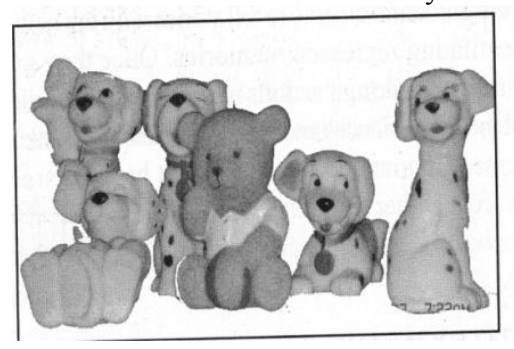

AIM: To understand the arunthathiyar child's family and how s/he feels about her/hisfamily members, emotional state of family members, the child's relationship with family members and the child's feelings.

\section{PROCESS:}

i. Make children to sit in a circle.

ii. Form sub - groups 3-4 memders

iii. Inform they are going to do the exercise on family protrait where they can draw protraits of immediate family members and also can protray significant members [relatives, neighbours, friends] in their life.

iv. Drawing the portraits label them with emotion expressions that the child is maintaining.

v. Do a model family protrait for them to be instructed.

vi. Start the activity with adequate explanation.

vii. By coming out of sub-group the has to present in a large group.

We are four members.My self, my mother and my sister my family he living separated and he is married to another women. And he is living with her when $i$ think about him $i$ hate him. When $i$ think of me I am unhappy due this circumstances.when I consider my sister living in hostel for studies and striving for studies I feel sad.when I recollect concerning my mother I am

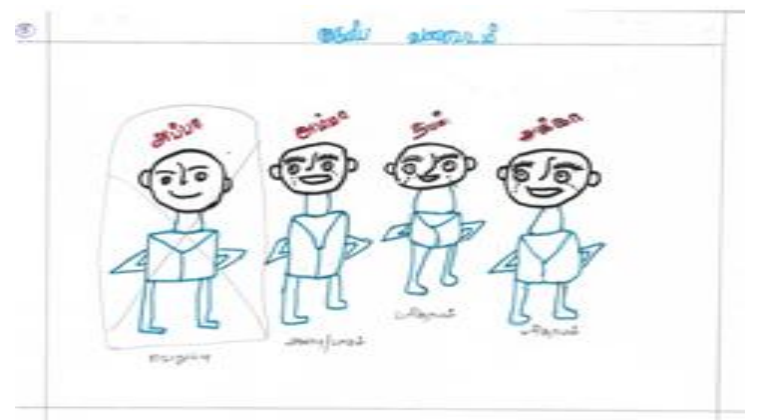

happy that she cares for knowing I am disabled with passing unhappy moments in my life.

\section{DRAWING}




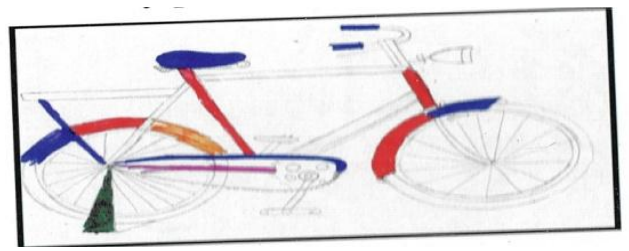

Arunthathiyar children sometimes are not comfortable sharing the disturbing incidences from their lives because of the pain and fear attached to the very thought of it. Articulating such a painful event can only happen when the arunthathiyar child is ready to recollect the incident. When the arunthathiyar child gets colour, he/she immediately starts exploring as to what he/she wants to draw. If the facilitator could guide the arunthathiyar child in such a situation, child will prepare him/herself mentally to express the painful scene that he/she witnessed on the paper. Once they express the suppressed feeling on the paper through drawing, the level of intensity of the emotions attached to the incident will decrease. At the first stage of the drawing exercise children are asked to draw their experience on "what happened". The second stage will take this process a little further and give confidence to arunthathiyar children to get over the losses they suffered by first accepting and then understanding the loss. It is difficult to get over a grief as long as the upsetting incidences keep disturbing unconsciously. So to come to terms with the loss, it is necessary to express the waves of emotion. So this understanding will gradually help them in coping with the situation and eventually getting back to a normal life with a positive outlook. The focus of the exercise from the third stage is to revitalize in children a sense of looking at the future with a positive and constructive outlook.

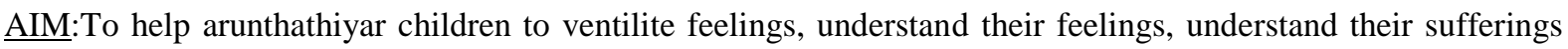
and help them develop a optimistic out look in arunthathiyar child's life through the artistic medium of drawing.

\section{PROCESS:}

i. Ask the children to form a semi-circle.

ii. Inform them that they are going to involve in drawing and painting activity under a theme - difficult circumstanceses

iii. Divide them into sub-groups and beautifully name them.

iv. Involve them in drawing.

v. Don't be jugemental and don't may them to copy during drawing activity.

vi. At the end of the activity ask them to share about incidence, losses, feelings about losses and about future.

\section{Stage 1: Painful event in my life}

The grand father who had parented me and my mother with love and affection had died and this is the unforgetable and painful incident in my life. When $i$ heard the demise of my grand father $i$ was shocked and thought very deeply with tears, who shall care for us? And I was unable to do anything for short time and afterwards I resumed from that shocking state. Our only support and refuge was my grandfather in whom we were clinging on for help. He was taking care of me form the age two and i am unable to forget him.

\section{Stage 2: Losses and difficulties}

My father's departure form our house is a greatest loss in our house. The love and care of my father is a great losses and mystery now for me. When I look at other children with their both their parents along with them in my village, $i$ am very must disturbed. I will be earning that my father in not like other fathers one brother who was residing near my house was very close and affectionate towards me. He went to the feild to feed the cattle with pastures and he had electric shock accident and he died. It was also another great loss for me.

Stage 3: How and what you want to be in future?

I should work as car mechanic and become an expert in th feild should look after my mother and my sister for that $i$ think $i$ should study still 

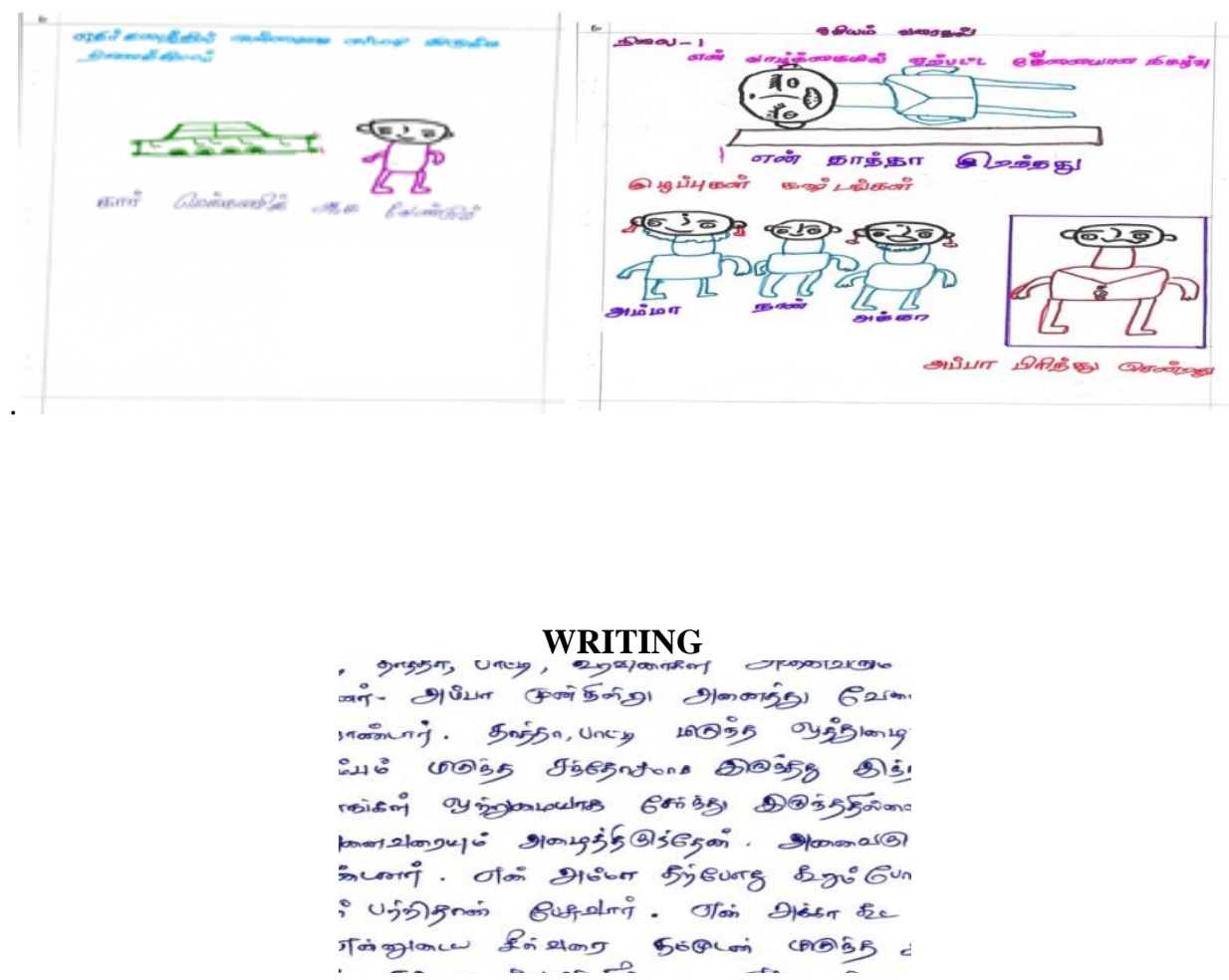

The writing exercise is designed into five stages to take arunthathiyar children through a gradual phase from coping and expressing the disturbing events to happy events from life and finally looking at the future with a positive attitude. Writing has been adopted as a medium here because many times arunthathiyar children find difficulty in articulating what they saw or what they are feeling. It is very natural that when pen and paper make contact, thoughts are released and the mind gets more focused as individuals are instinctively drawn towards the quiet center of the self. The beginning stage of the writing exercise might take arunthathiyar children through some of the unpleasant events because of the loss and trauma attached to it. However, it is important to help arunthathiyar children ventilate it out and then support them in coping with the situation. Instead of letting them trying to escape from constrained life towards a healthy mental growth, due to suppressing such strains and grief might result in other behavioural problems. At the later stage of the exercise arunthathiyar children are asked to write about pleasant things that make them happy in order to bring down the level of the stress and they are encouraged to look at the future with an optimistic outlook.

AIM:To help arunthathiyar children ventilate their feelings of disturbing event through the medium of writing and helping them to accept their feelings about the incident.The activity also aims at providing arunthathiyar children putdown the happiest moments in life and come into terms with the past by developing positive outlook in life.

\section{PROCESS:}

i. $\quad$ Make them to sit in semi - circle.

ii. Inform them that they are going to be involved in writing exercise.

iii. Distribute the materials for doing writing activity.

iv. Do not give time limitations.Discourge fast writing amoung children.

Note :-

a. Bothering event - Event that often comes to child's mind and disturbs him/her and makes him/her anxious.

b. Sad event - An incident that makes the child cry, feel disturbed, cheerless etc.

\section{Stage 1: Event that bothers me}

In my house we were living joyfully together.We were four members namely my self, my mother, my elder sister and father.My father got married to another strange women and had not returned home after some days. He has not thought about our families welfare little bit also. The debt started increasing and peace in the house started decreasing.These situation was bothering me so much and constantly problems started to prevail and bother me, which made me to drop out of school. All these incident makes me to get lot of pain and agony where i am unable to go forward in my lifes journey. 


\section{Stage 2: Thing I miss a lot in my life.}

My mother's guard parents are residing in puliampatti. I like my grand father very much. What ever doll $i$ ask for, he used to buy and give for me. He will teach me same indoor games and play along with me. He used to teach me some parables but my grandmother will be simply lamenting agairst me and my grandfather. When $i$ was studying $9^{\text {th }}$ std my grandfather died with a heart attack. My grand father was or only help in time of crisis and distress. Even my mother experienced broken heart and we received the death news, $i$ and my sister we in grief and we were crying and coming back to my grand fathers house to see him without life. It took many days to come back from the sad to normal state.we miss him a lot.

\section{Stage 3: Sad event in my life.}

I am very sad that my father and grand father is not with us and I am not able to study. This is the sadest event in my life.

\section{Stage 4: Happy event in my life}

Three years age my sisters ceremony had brought great joy for me in my life. In this function my father, mother, grandfather, grandmother and all my relatives look part and enjoyed together. My father was head of this function and he was leading us.My grand father and mother were great support for this function. I had invented my friends for this joyful day. This is the last fuction which we celebrated together with my father and grand father, in many occassions we used to recollect that happy moment and discuss about it occassinally and $i$ used to think about the reunion and my father with our family in my dreams.

\section{Stage 5: What can I do to make my life happy.}

At present due to family situation $i$ am working in wedding workshop to save my family in my future days. So in the comeing year $i$ am going to study $10^{\text {th }}$ std. And afterwards study Diploma in Automobile engineering. I have to study automobile Engineering and work in big car company i should make my self happy and have to change my mind to study.

\section{DOLLS}

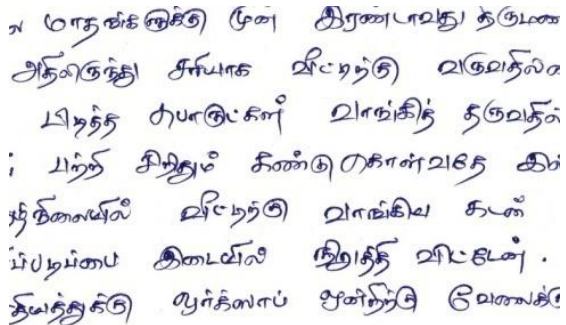

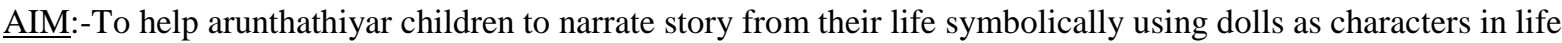
there by ventilating disturbing events in life.

\section{PROCESS}

Stage 1: Story in my life.

My fathers name is Jothimani. My sister name is Umamaheswari.She is studing B.Com my mother's name is jothimani. She is a coolie work. By doing coolie work, my mother is making us to study from my childhood days. $i$ am unable to walk properly. It is very difficult to walk sometimes $i$ will be more troubled in my heart that "Why I am walking like this? can walk like other?" In my school days $i$ have to walk one Kilometer and reach the school with difficully. All my friends walk fast and reach and leave me alone. I am unable to take part in outdoor games with other children. If $i$ think about that i feel very difficult. I am an average student in my class and all other students will mock at me very badly. If $i$ think about that I feel to neglect my school but $i$ studied with patience. My mother and community level worker in my village was motivating me to go attend classes and study. Till $8^{\text {th }}$ std studied in that school and after $8^{\text {th }}$ std 1 changed my school. My grand father died. My father remarried other strange woman. All these incident were makeing me very upset. Now $i$ was studing $10^{\text {th }}$ std Moreover financial crisis were hunting our life. I was unable to face the agony which my mother was facing and digest the situation which we are undergoing and my concentration in studies started to decrease more and more and $i$ become dropout child and I joined a welding workshop and $i$ am earning very little wages which is inadequate to built a satisfactory life. 


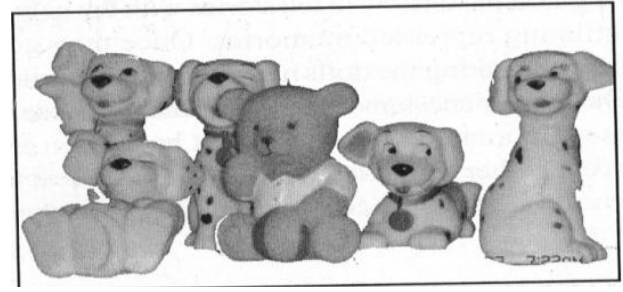

Clay modeling:

CLAY MODELLING

Clay modeling is the seventh medium, which is conducted in two phases. Often arunthathiyar children are unable to identify the emotions that they are experiencing. Clay can enable arunthathiyar children to release their feelings of despair by letting them mold any shape on them by beating., breaking, shaping and reshaping. Besides, the group exercise with arunthathiyar children can also play an important role in facilitating arunthathiyar children to develop a new relationship with the peer group. In the group arunthathiyar children will gradually come to realize that they are not the only ones to have faced difficulties in life but many others from their age group also have gone through the same. They will learn to respect each other's losses and help each other in a group to over come the same.

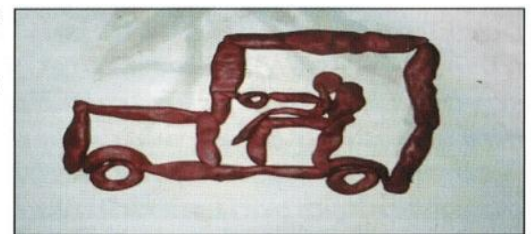

AIM:To help children to regulate their negative thoughts of losses towards positivism and help arunthathiyar children to give to their imagination using medium of clay.

\section{PROCESS:}

i. Ask children to sit in a semi-circle and divide them into small sub-groups.

ii. Give names of each sub-group.

iii. Distribute clay models and other materials for the activity

iv. Do the clay model according to theme and stages.

v. Finally make child to discuss the losses and things that makes happy among the children.

\section{Stage 1: Losses in my life}

My grand father was only help in time of want and distress. We have lost him due to severe heart attach it is a great loss which i had encountered in my life I was earning, thinking about him but finally came to a conclusion that it not reality to regain him. Regarding my father without consciousness he had left us and gone to a strange women and remarried her. It is a heat burning incident in our life.

\section{Stages 2: Things that make me happy}

Even though we have many problems in our house.My mother sacrifices for us and does many things for me and my sister. I have to come up infuture and look after my mother who buys for me food and clothing she will not allow anybody to scold me.My mother is my happiness in my life.

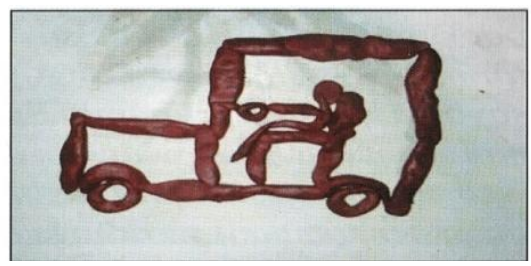

NON-PHARMOLOGICAL REHABILITATINGINTERVENTIONS THROUGH ADMINISTERING EFFCTIVE PSYCHOSOCIAL MEDIUMS:-

\section{Dealing with emotions of the child.}


Emotions encountered by in his difficult circumstances:

\begin{tabular}{|l|l|l|l|l|l|}
\hline Sadness & Anger & Fear & Feeling inferior & Cry & Hatredness \\
\hline
\end{tabular}

\begin{tabular}{|c|c|}
\hline \multicolumn{2}{|c|}{ Mediation to modify into healthy emotions: } \\
\hline Mediation for & What has been done \\
\hline Make him happy & $\begin{array}{l}\text { \# Highlighting positives from life of the child. } \\
\text { \# Engaging him in recreational activities. } \\
\text { \# Made him to enjoy nature. } \\
\text { \# Made him to mingle with friends and relatives } \\
\text { who are more concern about him. } \\
\text { \# Makeing leader in ckc. } \\
\text { \# Give him verbal praise. } \\
\text { \# Encourge smile and laughter whereever } \\
\text { necessary. } \\
\text { Made him understand need to be realistic on the } \\
\text { hand not be pesimistic. }\end{array}$ \\
\hline Removing anger & 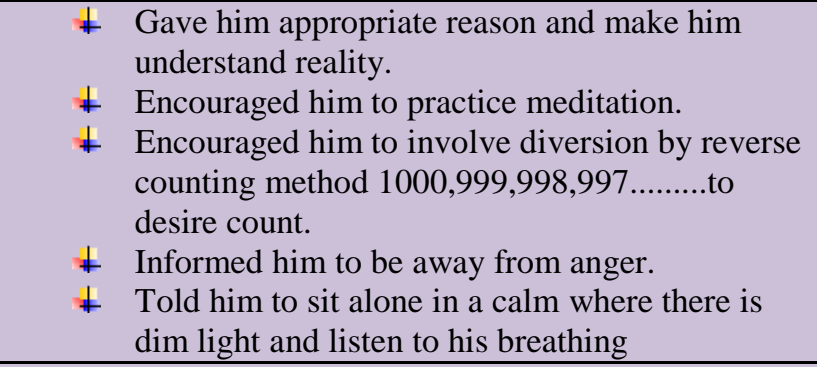 \\
\hline Removing fear & $\begin{array}{l}\text { \# Instellation of hope was done though giving } \\
\text { example from life of outstanding personalities. } \\
\text { \# } \text { Asked him to focus on positives thinking more. } \\
\text { \# } \text { Told him to contribution in term } \\
\text { education,home based activities and involve in } \\
\text { team work in community for productive work. } \\
\text { \# Eat healthy. } \\
\text { \# } \begin{array}{l}\text { Directed him to invoved in reading books which } \\
\text { boost up good qualities in life. }\end{array}\end{array}$ \\
\hline Feeling inferior & $\begin{array}{l}\text { \# Asked him to ventilate by seeking for help and } \\
\text { Adviced not to involve in solitary cry. } \\
\text { \# Asked him to be satisfied on what you have. } \\
\text { \# Told him to consider rejections are } \\
\text { oppurtunities. } \\
\text { \# Asked him to speak boaldly and dress up well. } \\
\text { \# Called his friend and asked him to list his } \\
\text { goodness which he found in him which had } \\
\text { exclulated his confidence }\end{array}$ \\
\hline Cry & $\begin{array}{l}\text { Highlighted the attainable hopes which he can } \\
\text { attain in the future. } \\
\text { Asked him to think all happy incidences in his } \\
\text { life. } \\
\text { \# Recollect all the achievements in life to avoid } \\
\text { cry }\end{array}$ \\
\hline Removal of hatredness & $\begin{array}{l}\text { * Informed him to seek for bare foot counselling } \\
\text { or professional counselling. }\end{array}$ \\
\hline
\end{tabular}

\section{Dealing with loses of the child through barefoot counseling:-}

The loses of the child are: 
Since the child has greater impact due to loses the emphasis was made to make him understand and motivated that life is a drama stage where people come in and go out.This material world is not permanent for us. So he was educatedto focuss on self efforts and forth comeing realities to come up in life.Through our skills we should change our loses into gain. The boy understood and confessed that "loses are not permanent can be regained or alternatives can be adopted through self efforts only"and also told "it is vain to trust man rather on self or some meta forces"

\section{Carrer guidance through barefoot counselling:-}

$>$ Gave barefoot counselling for the child to continue school and stop going to work.

$>$ He stopped going to work.

$>$ Received sponsor and joined him in computer center which is operated with Read's collaboration to learn basic IT skills to bridge his schooling.

$>$ Gave insight to the boy to join school in the month of april .Boy also agreed to join school [10th] in april month which will also be monitored.

\section{Barefoot counselling to his family members:}

Counselled the parent on importance of education among children who are towards development. Knowing the importance of education she told that she is educating her elder sister who is studing her undergrauduation course. And added that her son is faceing some learning difficulty and she had traced out why he is unable to study? Gave reply that problems in family made her son not have interest in her studies. Also she cried said, she has more experienced conflict in her family life. She was strengthened by making her negative emotions fade and She confessed after bare foot counselling that we will try to bring them out of learning and emotion problems through education after knowing the significance of education..

Planned interventions in the light of administering PSC mediums:For the child:-

\begin{tabular}{|l|l|}
\hline Interventions & Rationale \\
\hline Student enrichment programme & $\begin{array}{l}\text { To promote good study habits and exam } \\
\text { preparation methods in the boy. }\end{array}$ \\
\hline Life skills education & To promote psychosocial competencies \\
\hline Social skills training & To promote presentation skills in vivid situation \\
\hline Leadership training & To promote leadership qualities. \\
\hline Education about substance use & To nullify chances of using substances. \\
\hline Adolesence education programme & To protect adolescence safely \\
\hline
\end{tabular}

For the family:-

\begin{tabular}{|l|l|}
\hline Interventions & Rationale \\
\hline Family enrichment programme & $\begin{array}{l}\text { To built up healthy constructive single parent } \\
\text { family. }\end{array}$ \\
\hline Knowledge about the fedration in Read & $\begin{array}{l}\text { To avail assistance prescribed for marginalised } \\
\text { children. }\end{array}$ \\
\hline $\begin{array}{l}\text { Knowledge about the schemes, programme and } \\
\text { laws }\end{array}$ & To avail rights for the child. \\
\hline
\end{tabular}

\section{Outcome:}

$>$ Mastering emotions.

$>$ Improvement in communication

$>$ Adoption to stress and anger management skills.

$>$ Understand the development and changes through peer interaction

$>$ Positive behavioural change from behaviour.

$>$ Positive attitudinal change.

$>$ Building their self esteem

$>$ Imbibing skills for development

$>$ Decision making and problem solving.

$>$ improved disciplinary life amoung children.

$>$ Improved relationships by avioding fake friends.

$>$ Coordination and cooperation with the peer group.

\section{CONCLUSION:}


This way strengthening and enriching children is best and sucessfull way of enableing the children to be more functional.Thus the person who administer mediums will get an understanding that through the mediums the inner insights of the children can be identified.Psychosocial states can be improved through various psychosocial care mediums where support, justice and rehabilitation programs and regular follow up, with out any medical intervention. This medium based psychosocial care, support and rehabilitation is effective intervention changing the multiple difficult circumstance children being in to wellbeing.

Wellbeing has to be imparted among children where positive growth can be enhanced. Childhood is stage where we can develop and form the child. The biblical saying says that train up the child in the way he should grow, he not depart when he is old. Psychosocial wellbeing of children are of greater impotance because this psychosocial problems will lead to common mental health problems which may versen into major mental illness.Parents and teachers and community must participate in enhancing the psychosocial state of children

\section{Acronyms}

PSC -Psychosocial Care, PSCM-Psychosocial Care Mediums, CKC-Child Activity center

\section{ACKNOWLEDGEMENT.}

My extreme gratitude to Dr.Sekar, Proffesor in Psychiatric social worker who has encouraged me in proffessonal engagement and upliftmented me by mentoring. He has trained me to conduct many TOT programmes and hand holding trainningsfor empowerment of vitimised families in Tamilnad state. My hearfelt thanks to ICSSR for their financial support for publishing this article.

\section{BIBLIOGRAPHY}

[1] Sekar. k et al.(2008). Psychosocial care for children in difficult circumstances - My work book, Bengaluru:NIMHANS

[2] Sekar. K et al.(2012). Psychosocial care for children in difficult circumstances. Bangalore: NIMHANS

[3] Sam sangeeth. et al., (2010,January). Psychosocial care for children in difficult circumstances by community level workers - TN Experiences. Paper presented in symposium on Children in difficult circumstances in XXX Annual National Conference Of Indian Society Of Professional Social Work.

[4] Sekar. K et al.(2007). Psychosocial care for children, Medium-Drawing, Bengaluru: Everychild India.

[5] Sekar. K et al.(2007). Psychosocial care for children, Medium-Writting, Bengaluru: Everychild India.

[6] Sekar. K et al.(2007). Psychosocial care for children, Medium-Dolls, Bengaluru: Everychild India.

[7] Sekar. K et al.(2007). Psychosocial care for children, Medium-Facial expression, Bengaluru: Everychild India.

[8] Sekar. K et al.(2007) Psychosocial care for children, Medium-Clay modeling, Bengaluru: Everychild India.

[9] Sekar. K et al.(2007) Psychosocial care for children, Medium-Thematic expression, Bengaluru: Everychild India.

[10] Sekar. K et al.(2007) Psychosocial care for children, Medium- Family potrait, Bengaluru: Everychild India 